\title{
Staat van ongenade: Politiek onbehagen over de Nederlandse staat in de
}

jaren 2000

Verschenen als:

Kemmers, R., S. Aupers, D. Houtman en J. Van der Waal (2016) 'Staat van ongenade: Politiek

onbehagen over de Nederlandse staat in de jaren 2000’. Res Publica, 58 (4), pp 513-515.

\section{EEN SAMENVATTING VAN}

Kemmers, R., S. Aupers, D. Houtman \& J. van der Waal (2015) 'State of Disgrace: Popular Political Discontents about the Dutch State in the 2000s,' Parliamentary Affairs, 68 (3), pp. 476493 (link).

Roy Kemmers is als docent Sociologie verbonden aan het department of Social and Behavioural Sciences van het Erasmus University College in Rotterdam en als promvendus aan de afdeling Bestuurskunde en Sociologie van de EUR. Zijn onderzoeksinteresses omvatten naast politiek onbehagen thema's als identiteit, zingeving en cultuursociologie in het algemeen. Contact: kemmers@euc.eur.nl.

Stef Aupers is hoogleraar mediacultuur bij het Instituut voor Mediastudies aan de KU Leuven. Zijn onderzoek richt zich op de mediatisering van cultuur (o.a. religie, spiritualiteit en complotdenken) en game cultuur.

Dick Houtman is hoogleraar sociologie van cultuur en religie aan de KU Leuven. Recente boeken van zijn hand zijn Weber (in druk, met R. Laermans), Things: Religion and the Question of Materiality (2012, red. met B. Meyer), Farewell to the Leftist Working Class (2012 [2008], met P. Achterberg en A. Derks) en Paradoxes of Individualization (2011, met S. Aupers en W. de Koster). Meer info: www.dickhoutman.nl.

Jeroen van der Waal is universitair hoofdocent Sociologie aan de Erasmus Universiteit Rotterdam. Veel van zijn onderzoek beoogt te verklaren hoe sociale stratificatie verbonden is met waardeoriëntaties, stemgedrag en gezondheidsverschillen in Westerse landen. Voor meer informatie, zie www.jeroenvanderwaal.com. Contact: jeroenvanderwaal@gmail.com 
Overheden, politici en politieke partijen zijn de afgelopen decennia in Westerse samenlevingen uit de publieke gratie geraakt. Er wordt echter vooral in algemene termen over dit politiek onbehagen gesproken, waardoor het onduidelijk is waar dit onbehagen precies om gaat, en de manier waarop het door hen wordt geformuleerd. Er is, kortom, weinig zicht op hoe de burgers politiek begrijpen. In dit artikel onderzoeken we daarom politiek onbehagen in Nederland zoals dat door burgers zelf wordt geformuleerd.

In de gangbare praktijk om politiek onbehagen te onderzoeken onderscheiden we twee varianten met elk hun eigen merites en blinde vlekken. Allereerst is er de literatuur over populisme, die veel heeft bijgedragen aan begrip van het ideologische wereldbeeld dat populistische partijen en politici uitdragen in hun partijprogramma's en uitspraken. Het focust vaak echter exclusief op onbehagen zoals geformuleerd in de politiek-institutionele sfeer en leert ons minder over het onbehagen onder de mensen. Daarnaast is er onderzoek naar vertrouwen in de politiek onder de bevolking. Dit onderzoek heeft wel aandacht voor het onbehagen onder de bevolking, maar leunt op haar beurt sterk op survey-onderzoek. Dit onderzoek is uitstekend geschikt voor het analyseren van trends en het verklaren van verschillen, maar biedt minder inzicht in de klachten van burgers en de redenen die ze geven voor hun politieke onbehagen. Met de onderzoeksvraag “waar gaat het politieke onbehagen in Nederland over?” hopen we het hedendaagse politieke onbehagen beter te begrijpen, alsook de culturele voedingsbodem voor populistische partijen.

We bestuderen in deze case study het politiek onbehagen in Nederland in de periode 2000-2009, een periode waarin het politieke wantrouwen op de radar kwam en waarin het populisme in de politiek gestalte kreeg in de personen van (vooral) Pim Fortuyn en Geert Wilders. Om het 
onbehagen van burgers te onderzoeken hebben we besloten om de brievenrubriek van $D e$ Telegraaf te analyseren. Een brievenrubriek kan worden gezien als een vrij toegankelijke publieke sfeer. De brievenrubriek in De Telegraaf is bij uitstek een plek waar hedendaags politiek onbehagen wordt verwoord, gezien de anti-elitaire signatuur van die krant. We trokken eerst een representatieve steekproef uit het decennium aan brievenrubrieken ( $N=1186$ brieven) en selecteerden daarna brieven die uiting gaven aan zorgen, frustraties en ontevredenheden over de overheid, haar organisaties en ambtenaren, politici en politieke partijen, wat we samenvatten onder de noemer 'de staat'. Deze selectie van brieven $(n=120)$ is onderworpen aan een inhoudsanalyse volgens de principes van de gefundeerde theoriebenadering, wat resulteerde in drie typen van politiek onbehagen, bepaald aan de hand van de beschuldigingen die in de empirische analyse naar boven kwamen: 'de incompetente staat', 'de vervreemde staat,' en 'de corrupte staat'. De beschuldiging van 'de incompetente staat', allereerst, is gebaseerd op argumenten waarbij de staat heeft nagelaten haar taken uit te voeren en waarbij zij wordt gecorrigeerd door de betreffende brievenschrijvers. Zo schreef iemand over toenmalig minister Donner 'Hoe lang gaan we deze minister van Justitie nog laten klunzen en blunderen. En wanneer gaat hij zelf in zien dat Nederland klaar met hem is'. Kenmerkend voor dit type onbehagen is dat burgers vaak zelf oplossingen aandragen in de vorm van ontslag van de betrokken minister of burgemeester of een beleidsverandering. Het behelst, anders dan de volgende twee, geen omvattende systeemkritiek maar kaart concrete problemen aan.

Het vertoog van ‘de vervreemde staat’ komt voort uit beschuldigingen van Kafkaëske lege betekenisloosheid, van losgeslagen te zijn van de dagelijkse werkelijkheid, wat tot uiting komt in ervaringen met ondoordringbare bureaucratie en politici die niet weten wat er in de samenleving gebeurt. Wanneer de minister van Verkeer een experiment aankondigt om mensen 
die zich aan de regels houden te belonen. schrijft een lezer '[d]it experiment toont aan dat de regelgevers de controle volledig kwijt zijn.’ En als ondernemer, zo schrijft een ander, 'moet men zich met een kapmes een ondoordringbaar woud van veelal idiote regels zien te slechten voor men überhaupt aan de slag kan, laat staan het bedrijfje draaiend kan houden.’

Als laatste onderscheiden we 'de corrupte staat'. Terwijl het vorige type een amorele staat suggereerde, wordt hier duidelijk een immorele staat geschetst. Niet het algemeen belang wordt gediend, zo is de beschuldiging, maar in plaats daarvan staan persoonlijke, collectieve of ideologische belangen centraal. ‘[D]e macht [wordt] verdeeld op de manier die [gevestigde] partijen het beste uitkomt. Er is straks niets veranderd. Na de stoelendans der regenten is alleen paars een ander kleurtje geworden'. Een corrupte elite heeft de touwtjes in handen, zo luidt hierin de slotsom.

Deze studie toont een differentiatie binnen het politieke onbehagen in het begin van de $21^{\text {ste }}$ eeuw in Nederland. En het belang daarvan wordt duidelijk wanneer we deze differentiatie koppelen aan de ‘oplossingen’ die voor het 'probleem’ politiek onbehagen in de literatuur naar voren worden gebracht. Sommigen stellen dat burgers voorzien van informatie, of zorgen voor meer transparantie politiek onbehagen kunnen dempen. De hier gesuggereerde differentiatie van het onbehagen nuanceert deze claims. De geboden ‘oplossingen’ kunnen werken voor het onbehagen van het type 'incompetente staat', wat geïnterpreteerd kan worden als het vertoog van de mondige burger (critical citizens). Voor het onbehagen van de typen 'de vervreemde staat,' en 'de corrupte staat' - die duidelijk een algemener wantrouwen reflecteren - bieden ze waarschijnlijk weinig soelaas. Daarnaast kunnen die laatste typen onbehagen worden geïnterpreteerd als ‘populistisch’: het idee van een corrupte, van gewone mensen losgezongen 
elite. Daarmee wordt duidelijk dat populisme ook buiten het institutioneel-politieke veld waarneembaar is. Dit toont dat populisme ook goed kan worden onderzocht in tijden dat het niet wordt gearticuleerd in het politieke domein.

Een beperking van dit onderzoek is dat we vooral 'rechts onbehagen' hebben bestudeerd, gezien de signatuur van De Telegraaf. Toekomstig onderzoek, bijvoorbeeld naar ‘links onbehagen’, kan uitwijzen of onze typologie slechts een deel van het palet in politiek onbehagen onder Nederlandse burgers omvat. Daarnaast zou de keuze voor brieven naar krantenrubrieken (in plaats van bijvoorbeeld online inhoud) de generaliseerbaarheid kunnen beperken. Een laatste vraag voor toekomstig empirisch onderzoek die we oproepen is die naar de politieke consequenties van politiek onbehagen: leiden verschillende typen politiek onbehagen tot verschillende typen politiek gedrag? 